\title{
Utilization of sesbania leaves as sole feed in growing goats
}

\author{
M Shahjalal
}

\author{
Dept of Animal Nutrition, Bangladesh Agricultural University, Mymensingh 2202, Bangladesh
}

Sesbania, a tropical legume, providing green foliage of high crude protein and low crude fibre is commonly used for feeding goats. Lack of information on its utilization has evoked to study the effect of feeding sesbania leaves as sole feed on growth and nutrient utilization in growing Black Bengal goats.

Nine male castrated goats aged about 5 months and weighing $9.0 \mathrm{~kg}$ were used in a 56 day study. The animals were allocated at random to road-side grass (A), Sesbania aculeata (B) and Sesbania rostrata (C) and were fed to appetite. The changes in live weight and food intake were recorded weekly and a digestibility trial was conducted at the end of growth study.

Feeding of goats with sesbania leaves significantly improved DM consumption as well as the digestibility of all the nutrients except

$A$
-6.6
179
1.99

0.488
0.873
0.610

53.7
537
558

A

Live weight change $(g / d)$

DM intake $(\mathrm{g} / \mathrm{d})$

Est microbial-N yield $(\mathrm{g} / \mathrm{d})$

Digestibility $(\mathrm{g} / \mathrm{g})$

CP

$\mathrm{CF}$

OM

Nutritive value $(\mathrm{g} / \mathrm{kg} \mathrm{DM})$

DCP

TDN

"D" value (DOM) the CF compared with those given road-side grass. The daily average DM intakes were $20.6,25.5$ and $27.9 \mathrm{~g}$ per $\mathrm{kg}$ live weight in groups A, B and C, respectively, which indicated that leaves were more palatable to goats than grass. The DCP, TDN and DOM contents of Sesbania leaves were significantly higher than those of road-side grass. The increased DM consumption fed on sesbania leaves along with higher nutritive value resulted in significantly greater microbial-N yield and live weight gain. $S$. rostrata gave significantly higher values for nutrient digestibilities and DCP and DOM concentrations than $S$. aculeata.

The results indicate that road-side grass can not support the maintenance requirement of stall-fed goats and Sesbania rostrata, a highly palatable fodder, can be used a good source of nutrients for growing Black Bengal goats.

$\begin{array}{ccc}B & \text { C } & \text { SED } \\ 9.5 & 38.1 & 10.4^{\star} \\ 229 & 259 & 11.1^{\star \star} \\ 2.76 & 3.37 & 0.249^{\star} \\ & & \\ 0.685 & 0.837 & 0.0225^{\star \star} \\ 0.651 & 0.747 & 0.0684^{\star \star} \\ 0.634 & 0.718 & 0.0189^{\star} \\ 174 & & \\ 647 & 274 & 5.64^{\star *} \\ 580 & 703 & 26.3^{\star *} \\ & 652 & 17.2^{\star}\end{array}$

